\title{
Improving Anti-PD-1/PD-L1 Therapy for Localized Bladder Cancer
}

\author{
Florus C. de Jong ${ }^{1,+}+^{D}$, Vera C. Rutten ${ }^{1,+}{ }^{\mathbb{D}}$, Tahlita C. M. Zuiverloon ${ }^{1}$ and Dan Theodorescu ${ }^{2,3, *}$ \\ 1 Department of Urology, Erasmus University Medical Center, Erasmus MC Cancer Institute, \\ 3015 GD Rotterdam, The Netherlands; f.c.dejong@erasmusmc.nl (F.C.d.J.); v.rutten@erasmusmc.nl (V.C.R.); \\ t.zuiverloon@erasmusmc.nl (T.C.M.Z.) \\ 2 Samuel Oschin Comprehensive Cancer Institute, Cedars-Sinai Medical Center, Los Angeles, CA 90048, USA \\ 3 Departments of Surgery (Urology) and Pathology, Cedars-Sinai Medical Center, Los Angeles, CA 90048, USA \\ * Correspondence: dan.theodorescu@cshs.org; Tel.: +1-310-423-8431 \\ + These authors contributed equally to this work.
}

Citation: de Jong, F.C.; Rutten, V.C.; Zuiverloon, T.C.M.; Theodorescu, D. Improving Anti-PD-1/PD-L1 Therapy for Localized Bladder Cancer. Int. J. Mol. Sci. 2021, 22, 2800

https://doi.org/10.3390/ijms22062800

Academic Editor: Donald

J. Buchsbaum

Received: 11 February 2021

Accepted: 2 March 2021

Published: 10 March 2021

Publisher's Note: MDPI stays neutral with regard to jurisdictional claims in published maps and institutional affiliations.

Copyright: (c) 2021 by the authors. Licensee MDPI, Basel, Switzerland. This article is an open access article distributed under the terms and conditions of the Creative Commons Attribution (CC BY) license (https:// creativecommons.org/licenses/by/ $4.0 /$ )

\begin{abstract}
In high-risk non-muscle invasive bladder cancer (HR-NMIBC), patient outcome is negatively affected by lack of response to Bacillus-Calmette Guérin (BCG) treatment. Lack of response to cisplatin-based neoadjuvant chemotherapy and cisplatin ineligibility reduces successful treatment outcomes in muscle-invasive bladder cancer (MIBC) patients. The effectiveness of PD-1/PD-L1 immune checkpoint inhibitors (ICI) in metastatic disease has stimulated its evaluation as a treatment option in HR-NMIBC and MIBC patients. However, the observed responses, immune-related adverse events and high costs associated with ICI have provided impetus for the development of methods to improve patient stratification, enhance anti-tumorigenic effects and reduce toxicity. Here, we review the challenges and opportunities offered by PD-1/PD-L1 inhibition in HR-NMIBC and MIBC. We highlight the gaps in the field that need to be addressed to improve patient outcome including biomarkers for response stratification and potentially synergistic combination therapy regimens with PD-1/PD-L1 blockade.
\end{abstract}

Keywords: bladder cancer; BCG-unresponsive; neoadjuvant chemotherapy; immune checkpoint inhibition; PD-1; PD-L1

\section{Introduction}

Bladder cancer (BC) is among the ten most common cancers worldwide with 550k new cases yearly and 200k deaths in 2018 [1]. BC is classified into non-muscle invasive (NMIBC) and muscle invasive bladder cancer (MIBC) [2,3]. Based on molecular [3] and clinicalpathological features, a subgroup of NMIBC patients are defined as having high-risk disease (HR-NMIBC), which indicates a high risk of disease recurrence and progression to MIBC [3]. To lower this risk in HR-NMIBC, patients are treated with a transurethral resection followed by intravesical instillations with Bacillus Calmette-Guérin (BCG) immunotherapy [4]. Despite this approach, $235 \%$ of HR-NMIBC patients develop high-grade (HG) recurrences and $\sim 20 \%$ develop disease progression to MIBC [5,6]. These so called "BCG-unresponsive" patients are exposed to unnecessary BCG toxicity without any benefit, and for these patients the recommended treatment is surgical removal of the bladder (radical cystectomy (RC)) with a urinary diversion [2,3,7]. Yet some patients have comorbidities that preclude them from a RC, a surgical procedure associated with significant morbidity and mortality, while others have a strong desire for bladder-sparing treatments [2,6,8-10]. In addition, as some BCG-unresponsive patients recur without progression to MIBC, a RC may be considered as overtreatment. In summary, both HR-NMIBC and MIBC patients have an urgent need for better treatments.

In recent years, anti-PD-1/anti-PD-L1 immune checkpoint inhibition (ICI) has been proposed as new treatment modality in both BCG-unresponsive HR-NMIBC and MIBC. 
However, as in metastatic MIBC, clinical response rates to ICI seem unsatisfying. Here, we present a review on the rationale and use of PD-1/PD-L1 inhibition in localized BC. Secondly, we discuss opportunities and challenges on how to improve the response rate to PD-1/PD-L1 ICI using synergistic treatment regimens.

\section{Evidence Acquisition}

A literature search was conducted using ClinicalTrials.gov for ongoing trials on PD1/PD-L1 combination therapy in localized BC until 1 February 2021. The search strategy was as follows: Bladder Cancer (Condition or Disease) and PD-1 or PD-L1 or any FDA approved PD-1/PD-L1 inhibitors, namely pembrolizumab, atezolizumab, nivolumab, durvalumab, avelumab or cemiplimab (Other Terms). The search resulted in 350 registered trials, six additional trials were identified from other review articles [11-13]. After removal of duplicates and terminated trials, 191 trials were assessed for eligibility. Trials with PD-1/PD-L1 ICI combined with chemotherapy, radiotherapy, other immune checkpoint inhibitors or targeted treatments were included. Other non-targeted treatments (e.g., BCG) and studies involving metastatic BC patients were excluded. A total of 37 clinical trials were included in this systematic review (Figure 1). NCT number, population, timing, phase, antibody, additional treatment and primary endpoints were collected for each trial.
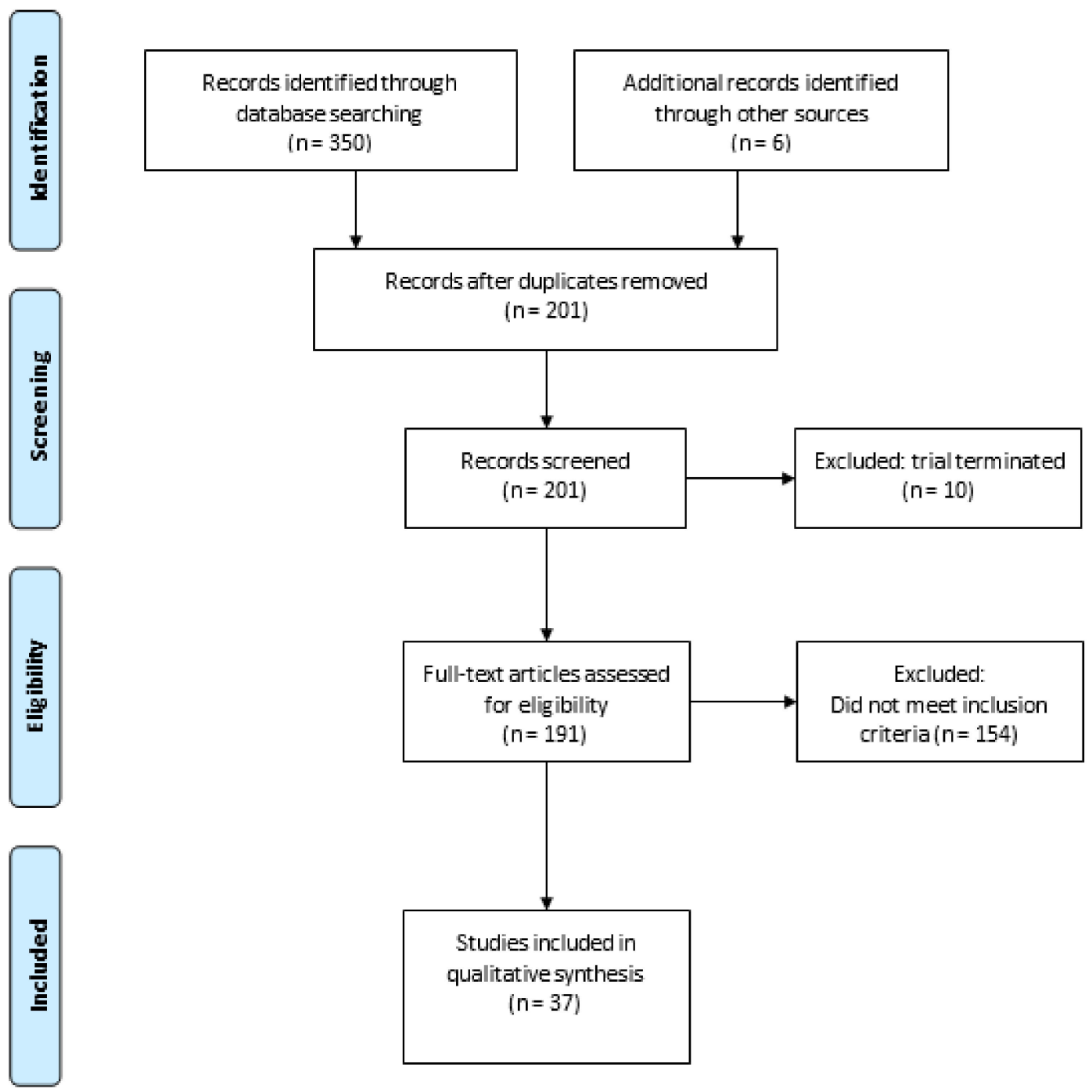

Figure 1. PRISMA flow diagram of evidence acquisition. 


\section{Immune Checkpoint Inhibition}

\subsection{Rationale for Anti-PD-1/PD-L1 Treatment}

The checkpoint protein Programmed Cell Death Protein 1 (PD-1) is expressed in activated T lymphocytes and regulates $\mathrm{T}$ cell effector functions [14]. PD-1 restrains T cell immune responses [15]. As PD-1 engages with its ligand, programmed death-ligand 1 (PD-L1), T cell exhaustion occurs, thereby downregulating T cell activity-which is currently believed to be a mechanism to prevent auto-immunity $[16,17]$. The discovery that the PD-1/PD-L1 axis is involved in T cell regulation led to preclinical studies demonstrating that PD-1/PD-L1 is often overexpressed in malignant cells, and several in vivo experiments showed that inhibition of PD-1 caused tumor rejection in mice, whereas induced overexpression of PD-L1 led to tumor colonization and disease progression [15]. In a syngeneic mouse model, with orthotopically implanted MB49 BC cell lines, treatment of mice with a PD-L1 inhibitor (Avelumab) led to a significant tumor reduction compared to BCG alone or a combination regimen [18]. Treatment with BCG and PD-L1 blockade was evaluated in a chemically induced rat bladder tumor model [19]. Interestingly, BCG treatment upregulated PD-L1 expression in tumor tissue, and combined BCG plus anti-PD-L1 therapy demonstrated tumor weight reduction and boosted circulating CD8+ immune responses as compared to BCG alone.

In human samples, several studies showed that PD-1/PD-L1 expression was higher in tumor tissue specimens from BC patients as compared to normal tissue [14,20-22]. A metaanalysis in localized bladder cancer found that PD-L1 expression in tumor cells, as assessed by immunohistochemistry (IHC) and different monoclonal antibodies, was correlated to a poorer clinical outcome in BC, but only two studies specifically looked at HR-NMIBC [23]. Interestingly, PD-L1 tumor expression was associated with a higher tumor stage and grade, with abundant expression in BCG-induced granulomata of BCG-unresponsive patients [22]. BCG-unresponsive patients showed upregulation of PD-L1 expression in both tumor and immune cells compared to BCG-responders, and RNA-sequencing revealed baseline PD-L1 to be higher in BCG-unresponsive patients [22,24,25]. Notably, IHC studies did not find a correlation of PD-L1 expression with disease recurrence in BCG-unresponsive patients $[25,26]$. All in all, the PD-1/PD-L1 pathway seems implicated in the immune response of localized $\mathrm{BC}$.

\subsection{Biomarkers Predicting Response to Anti-PD-1/PD-L1 Treatment}

Based on Phase III studies, ICIs are now included in major urology guidelines for use as second-line treatment in platinum-relapsed patients, and as first-line treatment in platinum-ineligible metastatic bladder cancer patients on the condition of high PD-L1 tumor cell expression [2]. Despite high PD-L1 expression by IHC, many BC patients do not respond to PD-1/PD-L1 inhibitors, so more accurate biomarkers are needed. Thus far, three systematic reviews reported on the use biomarkers in advanced BC and concluded that none of the current biomarkers were of sufficient quality for use in clinical practice [27-29].

\subsection{PD-1/PD-L1 Effectiveness Studies}

Several studies are exploring usage of PD-1/PD-L1 monotherapy in localized BC. Currently, no studies have been published on ICI in BCG-unresponsive NMIBC. However, in the Phase-II Keynote-057 study, pembrolizumab monotherapy is being investigated in BCG-unresponsive patients [30]. Interim analyses showed a pathological complete response (pCR) rate at 3 months of $40.6 \%(n=102)$, with 18 patients having a durable CR of $\geq 12$ months. The median follow-up was 28.4 months. In patients that underwent a RC due to ICI treatment failure, three had $\geq$ pT2 disease at the time of RC. Thus far, no published data is available on the use and efficacy of biomarkers in the BCG-unresponsive setting.

In MIBC, two Phase II studies, PURE-01 and ABACUS, have published results [12,31-33]. In PURE-01, pembrolizumab was used as neoadjuvant ICI, after which a $37 \%(n=42) \mathrm{pCR}$ rate was observed at $\mathrm{RC}$, whereas $55 \%(n=63)$ of patients were downstaged to NMIBC [32]. Overall, 24-month recurrence-free survival (RFS) was 71.7\% in 143 patients; RFS based 
on pathological staging ranged from $95.9 \%$ for pCR, $78.8 \%$ for localized $\mathrm{BC}$ and $39.3 \%$ for patients with lymph node disease [34]. High tumor mutational burden (TMB) from pre-pembrolizumab TURBT samples was associated with an increased probability of $\mathrm{pCR}$ $(p=0.02)$ in univariate analysis of pre-treatment samples. Post-pembrolizumab TMB was lower compared to baseline TMB (5.0 Mb vs. $10.1 \mathrm{Mb}, p=0.005)$ in 24 matched pre-post treatment samples, suggesting subclonal ICI-resistant tumor expansion [35]. The presence of DNA damage response (DDR) and/or retinoblastoma protein 1 (RB1) gene alterations $(52 \%)$ were associated with an increased TMB and likelihood of pCR [35]. qPCR analyses of 14 tumor samples of patients without $\mathrm{pCR}$ after pembrolizumab revealed upregulation of genes associated with interferon- $\gamma($ IFN- $\gamma$ ) and resistance to immune therapy posttreatment compared to baseline [35]. The ABACUS trial reported an overall $\mathrm{pCR}$ rate of $31 \%$ after treatment with atezolizumab [35]. TMB at baseline was not associated with treatment outcome. Using IHC, patients with $\mathrm{pCR}$ demonstrated increased CD8 $(p=0.04)$ and PD-L1 ( $p=0.21$, SP142 levels) and decreased expression of fibroblast activation protein (FAP) compared to patients without pCR (both $p<0.01$ ). An 8-gene cytotoxic T cell signature moderately stratified patients for outcome after ICI. A previously developed TGF- $\beta$ signature was unable to stratify patients.

Overall, PD-1/PD-L1 blockade for localized BC is encouraging, but interpretation of data is hampered by small sample size, a lack of independent validation and patientderived pre-clinical models for hypothesis testing [27]. Moreover, based on relatively low overall response rates of Keynote-057, PURE-01 and ABACUS, there is clearly room for improvement.

\section{Opportunities to Improve Efficacy of PD-1/PD-L1 Inhibition}

\subsection{Combined Treatment with Platinum-Based Chemotherapy}

Combining PD-1/PD-L1 inhibitors with platinum-based chemotherapy (PBC) may increase tumor immunogenicity [36]. $\mathrm{PBC}$ causes DNA damage and induces cell death, thereby attracting antigen presenting cells (APC) [37]. PBC also increases TMB, and tumorspecific neoantigens are presented by MHC-1 and cause cytotoxic T cell activation [38] While MHC-1 is often downregulated in cancer, in vitro experiments have shown that PBC induces MHC- 1 on tumor cells $[36,39,40]$. IL-12 is essential for antigen presentation; in vivo knockout experiments showed that $\mathrm{PBC}$ increases dendritic cell (DC) maturation and leads to an increased ability of DCs to present antigens in an IL-12 dependent manner, resulting in the hypothesis that PBC sensitizes tumors for immune recognition [41]. Experiments in a murine model revealed that $\mathrm{T}$ cell costimulatory molecules such as CD80/CD86 are increased in tumor infiltrating immune cells after cisplatin treatment, suggesting that CD80/CD86 expression can be modulated by cisplatin treatment [42]. In vitro experiments showed that PBC induces PD-L1, making PD-L1 an interesting target to inhibit after PBC [39,43-45]. PBC may also decrease PD-L2 expression via modulation of the transcriptional regulator STAT6 [46]. As PD-L2 competes with PD-L1 to bind PD-1, decreased expression of PD-L2 after PBC results in enhanced affinity of PD-L1 to PD-1, and increases the relevance of PD-L1 for ICI [47]. The beneficial effects of the addition of PBC to PD-1/PD-L1 blockade is summarized in Figure 2A.

The favorable effects of combined ICI and $\mathrm{PBC}$ have been shown in numerous studies [48]. In an MB49 BC subcutaneous model, anti-PD-L1 combined with PBC was more effective than either therapy alone [49]. In an MBT-2 subcutaneous model, anti-PD-L1 combined with PBC was more effective than PBC alone, but counterintuitively, anti-PD-L1 monotherapy was most effective, suggesting that combined treatment results are modeldependent [49]. Immune profiling of baseline tumors by flow cytometry did not demonstrate differences of tumor immune cell populations, and both MB49 and MBT-2 tumors were highly enriched with myeloid-derived suppressor cells (MDSCs). However, expression of the TIGIT checkpoint proteins on immune cells were decreased after PBC treatment in the MB49 vs. MBT-2 model, and the authors suggest that TIGIT may play a role in the diverse anti-tumor responses between models. 


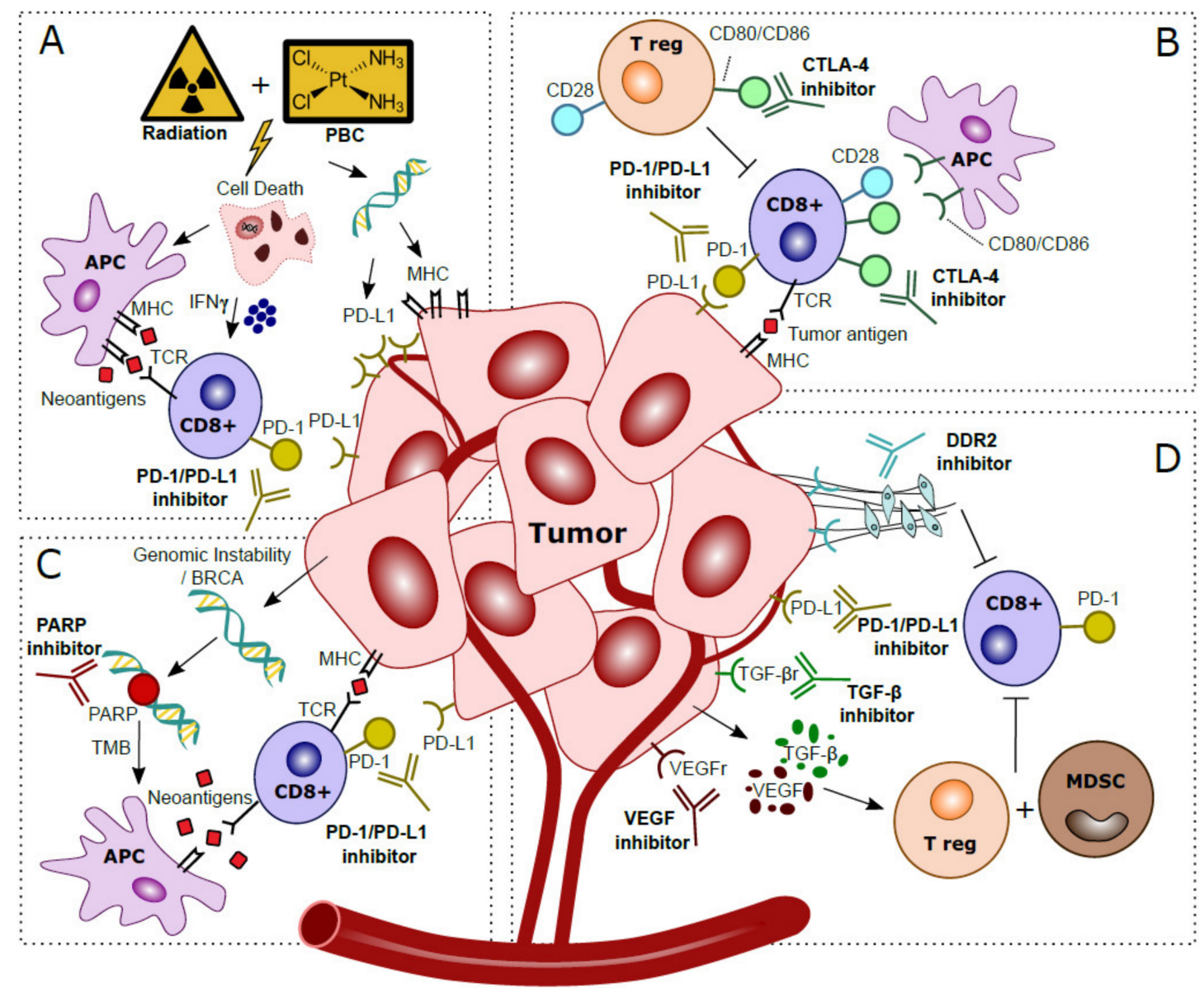

Figure 2. Hypothesized mechanisms of combination treatments to improve clinical response to anti-PD-1/PD-L1 treatments in localized bladder cancer patients. (A) Platinum-Based Chemotherapy (PBC) and/or radiation prompts tumor cell death. This process attracts Antigen Presenting Cells (APC), which upregulate presentation of tumor-specific neoantigens to cytotoxic T cells. Activation via IFN- $\gamma$ released in the tumor microenvironment stimulates anti-tumor immunity. Direct effects of DNA damage by PBC and radiation cause upregulated expression of PD-L1 and MHC in tumor cells. (B) CTLA-4 checkpoint inhibitors block CTLA-4 on CD8+ T cells and T regulatory (T reg), thereby further stimulating CD28-CD80/CD86 T cell co-stimulatory responses and anti-tumor immunity. (C) Genomic instability is observed in tumor cells, especially in patients with BRCA alterations. The inability to restore DNA damage with blockade of PARP, normally used for DNA repair, leads to more somatic mutations, a higher Tumor Mutational Burden (TMB) and more tumor-specific neoantigens. Neoantigens are presented by Antigen Presenting Cells (APC) to provoke additional cytotoxic T cell responses. (D) Blockade of VEGF and TGF- $\beta$ excreted by the tumor prevents activation of T regulatory cells (T reg) and Myeloid Derived Suppressor Cells (MDSC) that caused an immunosuppressive microenvironment. Inhibition of DDR2 prevents development of Cancer Associated Fibroblasts (CAFs), which stimulated metastases and yielded additional immune suppressive effects and increased CD8+ T cell infiltration.

Multiple clinical trials evaluate a combination of PBC with PD-1/PD-L1 ICI in MIBC (Table 1) [13]. Neoadjuvant pembrolizumab plus gemcitabine/cisplatin showed a partial response rate to NMIBC at RC of $61 \%(n=36)$ (NCT02365766) [50]. In BLASST-1, a multicenter Phase II trial, PBC combination therapy with nivolumab demonstrated a very high pCR rate of $65.8 \%(n=27)$ [51]. Gemcitabine combined with pembrolizumab for cisplatinineligible patients yielded results comparable to pembrolizumab alone in NCT02365766, a Phase 1b/II study: 45.2\% achieved pCR, whereas 51.6\% reached <pT1N0 [52]. Interim analysis of SAKK06/17 showed pCR in 30\% $(n=9)$ after treatment with gemcitabine and durvalumab pre- and post-operatively, whereas $20 \%$ of patients reached non-muscle invasive disease (pT1/pTis) [53]. Preclinical studies and interim study reports are encouraging and suggest a synergistic effect of chemotherapy with PD-L1 blockade. However, pCR rates 
are a surrogate marker for actual clinical outcome, thus long-term results analyzing disease progression are necessary. More information on treatment sequence and timing of PBC with ICI is also needed before these alternative treatment paradigms can be implemented.

Table 1. Studies investigating anti-PD-1/PD-L1 combined with chemo- and/or radiotherapy in localized bladder cancer.

\begin{tabular}{|c|c|c|c|c|c|c|}
\hline NCT Number & Population & Timing & Phase & PD-1/PD-L1 & Addition & Endpoint(s) \\
\hline NCT03294304 & T2-T4a N0 M0 MIBC & Neoadjuvant & 2 & Nivolumab & Gem/cis & $\mathrm{pRR}$ \\
\hline NCT02690558 & T2-T4a N0 M0 MIBC & Neoadjuvant & 2 & Pembrolizumab & Gem/cis & pDS to $<$ pT2 \\
\hline NCT03406650 & T2-T4a N0-1 M0 & $\begin{array}{c}\text { Neoadjuvant }+ \\
\text { adjuvant }\end{array}$ & 2 & Durvalumab & Gem/cis & EFS \\
\hline NCT03661320 & T2-T4a N0 M0 & Neoadjuvant & 3 & Nivolumab & $\mathrm{Gem} / \mathrm{cis}$ & pCRR, EFS \\
\hline NCT03924856 & $\begin{array}{l}\text { T2-T4a N0 M0 or } \\
\text { T1-T4a N1 M0 }\end{array}$ & Neoadjuvant & 3 & Pembrolizumab & Gem/cis & pCRR, EFS \\
\hline NCT03732677 & T2-T4a N0-1 M0 & $\begin{array}{c}\text { Neoadjuvant }+ \\
\text { adjuvant }\end{array}$ & 3 & Durvalumab & Gem/cis & pCRR, EFS \\
\hline NCT03558087 & T2-T4a N0 M0 & Neoadjuvant & 2 & Nivolumab & Gem/cis & CRR, pCRR \\
\hline NCT04099589 & T2-T4a N0 M0 & Neoadjuvant & 2 & Toripalimab & Gem or cis & pCRR \\
\hline NCT03674424 & T2-T4a Nx M0 & Neoadjuvant & 2 & Avelumab & $\begin{array}{l}\text { Gem/cis or } \\
\text { ddMVAC or } \\
\text { paclitaxel + } \\
\text { gemcitabine }\end{array}$ & pCRR \\
\hline NCT02365766 & T2-T4a N0 M0 & Neoadjuvant & $1 / 2$ & Pembrolizumab & $\begin{array}{l}\text { Gem/cis or } \\
\text { gemcitabine }\end{array}$ & AE, PalR \\
\hline NCT04164082 & BCG-unresponsive & Neoadjuvant & 2 & Pembrolizumab & $\begin{array}{l}\text { Gemcitabine } \\
\text { hydrochloride }\end{array}$ & CRR, EFS \\
\hline NCT02560636 & T2-T4a N0-3 M0-1 & Neoadjuvant & 1 & Pembrolizumab & Radiotherapy & MTD, AE \\
\hline NCT02891161 & T2-T4a N0-2 M0 & Neoadjuvant & 2 & Durvalumab & Radiotherapy & DLT, PFS, DCR \\
\hline NCT03950362 & BCG-unresponsive & $\begin{array}{l}\text { Ineligible/refusal } \\
\text { of RC }\end{array}$ & 2 & Avelumab & Radiotherapy & RFS \\
\hline NCT03317158 & BCG-unresponsive & Neoadjuvant & $1 / 2$ & Durvalumab & $\mathrm{EBRT}+\mathrm{BCG}$ & $\begin{array}{l}\text { Recommended } \\
\text { dose, RFS }\end{array}$ \\
\hline NCT03775265 & T2-4a N0 M0 & Bladder sparing & 3 & Atezolizumab & $\begin{array}{c}\text { Gem or CIS or } \\
\text { fluorouracil + } \\
\text { MMC + } \\
\text { radiotherapy }\end{array}$ & EFS \\
\hline NCT02662062 & T2-T4a Nx M0 & $\begin{array}{l}\text { Ineligible/refusal } \\
\text { of RC }\end{array}$ & 2 & Pembrolizumab & $\begin{array}{l}\text { Cisplatin }+ \\
\text { radiotherapy }\end{array}$ & AE (grade 3-4) \\
\hline NCT02621151 & T2-T4a N0 M0 & $\begin{array}{l}\text { Ineligible/refusal } \\
\text { of RC }\end{array}$ & 2 & Pembrolizumab & $\begin{array}{l}\text { Gemcitabine + } \\
\text { radiotherapy }\end{array}$ & DFS \\
\hline NCT03617913 & T2-T4a N0 M0 & Neoadjuvant & 2 & Avelumab & $\begin{array}{l}\text { Flourouracil + } \\
\text { MMC or cisplatin } \\
\text { and radiotherapy }\end{array}$ & CRR \\
\hline NCT03702179 & $\mathrm{T} 2-\mathrm{T} 4 \mathrm{a}$ & Neoadjuvant & 2 & Durvalumab & $\begin{array}{c}\text { Tremelimumab + } \\
\text { radiotherapy }\end{array}$ & pRR \\
\hline NCT03601455 & $\mathrm{T} 2-\mathrm{T} 4 \mathrm{a}$ or $\mathrm{N}+/ \mathrm{M}+$ & Ineligible for RC & 2 & Durvalumab & $\begin{array}{c}\text { Tremelimumab + } \\
\text { EBRT }\end{array}$ & AE, PFS \\
\hline NCT03549715 & T2-T4a N0-1 M0 & Neoadjuvant & $1 / 2$ & Durvalumab & $\begin{array}{c}\text { Tremelimumab + } \\
\text { ddMVAC }\end{array}$ & $\mathrm{AE}, \mathrm{pCRR}$ \\
\hline
\end{tabular}

$\mathrm{AE}=$ adverse events, $\mathrm{DCR}=$ disease control rate, ddMVAC $=$ dose dense methotrexate vinblastine doxorubicin cisplatin, $\mathrm{DFS}=$ disease-free survival, DLT = dose limiting toxicity, EFS = event-free survival, EBRT = External Beam Radiotherapy, Gem/cis = gemcitabine/cisplatin, $\mathrm{MMC}=$ mitomycine $\mathrm{C}, \mathrm{MTD}=$ maximum tolerated dose, $\mathrm{PalR}=$ pathologic muscle invasive response rate, $\mathrm{p}(\mathrm{C}) \mathrm{RR}=$ pathological $($ complete $)$ response rate, $\mathrm{pDS}$ = pathological downstaging, $\mathrm{PFS}$ = progression-free survival, RFS = recurrence-free survival. 


\subsection{Combined Treatment with Radiotherapy}

Ionizing radiation induces double-stranded DNA breaks and produces reactive oxygen species (ROS) leading to cell cycle arrest, apoptosis and cell death [54,55]. Radiation elicits immunogenic effects within the tumor microenvironment (TME) by upregulating and activating the complement pathway and stimulation of IFN- $\gamma$ release, both implicated in tumor eradication $[56,57]$. Radiotherapy enhances the adaptive immune system by upregulation of MHC-I, increasing cytotoxic T cell activity. Combining radiotherapy with immune-modulation may inhibit cancer via APC cross-presentation and improvement of T cell priming [58-61]. By inducing genotoxic stress, radiation prompts NK-mediated innate immune responses [62]. Interestingly, radiation also elicits chemotactic signals that attract MDSCs, instigating T-cell suppression [63,64]. Immunosuppressive effects can also be induced via activation of TGF- $\beta$, leading to upregulation of PD-L1 on tumor cells [65]. Combined radiotherapy with PD-L1 inhibition led to synergistic anti-tumor effects in vivo, thus providing the rationale for combined regimens with anti-PD-1/PD-L1 drugs (mechanism depicted in Figure 2A) [66-69]. Anti-PD-L1 therapy started one day prior and continued until two weeks after local irradiation (12Gy) in an HT1197/MB49 mouse model led to significant tumor growth delay compared to monotherapy [70].

Radiation may have immune-mediated distant effects, termed the abscopal effect, which refers to regression of non-irradiated lesions located elsewhere than the primary radiated site [62]. The abscopal effect is more often detected in mice treated with a combination of radiotherapy and PD-1/PD-L1 than radiation alone [65,71,72]. The underlying mechanism remains unclear, but it is hypothesized that anti-tumor immune responses are amplified. Taken together, radiation therapy stimulates tumor immunogenicity and suggests higher PD-1/PD-L1 susceptibility, hence combined regimes are appealing for investigation in patients with localized $B C$ who prefer a bladder-sparing treatment $[59,60,73]$. Issues that need to be resolved include determining the optimal fractioning of radiotherapy, timing of ICI and an appropriate balance with regard to side effects associated with each modality $[74,75]$. Currently, multiple trials investigating radiotherapy and PD-1/PD-L1 blockade in BC are underway but none have been published so far (Table 1) [11].

\subsection{Combined Treatment with Anti-CTLA-4}

For optimal cytotoxic T cell-mediated tumor response, co-stimulation by CD80/CD86 binding to CD28 is required. CD28-CD80/CD86 interaction leads to increased T cell proliferation, differentiation and survival [76]. CTLA-4, a CD28 homolog, is another checkpoint-inhibitor expressed by T cells. CTLA-4 binds competitively with CD80/CD86 on APC's, resulting in downregulation of T cell proliferation and response. Hence, CTLA-4 blockade can facilitate $\mathrm{T}$ cell recognition and increases eradication of malignant cells, thus strengthening the immunological response (illustrated in Figure 2B) [77,78].

In vivo mouse models studying melanoma, ovarian and colon carcinoma showed higher tumor rejection rates and increased tumor induced lymphocyte activity and proliferation after combined therapy with CTLA-4 and PD- 1 compared to monotherapy $[79,80]$. Combining CTLA-4 and PD-L1 inhibitors yields increased CD8+ and CD4+ counts, reduced CD4+ Tregs, increased expression of pro-inflammatory cytokines and a polarization shift from M2 to M1 macrophages [81]. In another study, MB49 BC cells were injected subcutaneously in C57Bl/ 6 female mice to investigate the response to anti-PD-1 vs. anti-CTLA-4 alone or combined treatment and found that the combination showed increased circulating CD8+ T cells and superior overall survival compared to each monotherapy. In a control group, BCG treatment had no effect on tumor growth [82]. These results were confirmed in a second study that investigated a combination of anti-PD-1/anti-CTLA-4 in an orthotopic mouse model [83].

The NABUCCO-trial recently demonstrated a $46 \%$ pCR rate after treatment with ipilimumab (anti-CTLA-4) and nivolumab (anti-PD-1) prior to RC in cisplatin-ineligible stage III BC patients [84]. Of 24 patients, $14(58 \%)$ reached either non-muscle invasive disease or $\mathrm{PCR}$. Biomarker analysis revealed that tumors from $\mathrm{PCR}$ had higher frequencies 
of DDR alterations compared to non-pCR tumors $(p=0.03)$, and trended towards a higher TMB $(p=0.056)$ [84]. An increased TGF- $\beta$ expression signature was associated with non-response, while response was independent of baseline CD8+ presence or T-effector signatures. However, upregulation of B cell-related genes at baseline correlated with non-response. Non-responding tumors exhibited more stromal B cells than responding tumors $(p=0.043)$ whereas the density of $\mathrm{B}$ cells in the tumor compartment was higher $(p=0.07)$ [84]. Overall, NABUCCO indicates that combination regimens with anti-CTLA-4 blockade should be investigated further, as the $\mathrm{pCR}$ results are promising. Other studies investigating CTLA-4 plus PD-1/PD-L1 combinations are illustrated in Tables 1 and 2. No combination regimes have reported data in HR-NMIBC, but considering toxicity profiles, ICI combinations might also prove useful in BCG-unresponsive patients. The extent to which auto-immune symptoms will develop and whether they are manageable will likely determine if combination therapies are feasible and safe [85].

Table 2. Studies investigating anti-PD-1/PD-L1 combined with immune checkpoint inhibitors and targeted treatments.

\begin{tabular}{|c|c|c|c|c|c|c|}
\hline NCT Number & Population & Timing & Phase & $\begin{array}{l}\text { PD-1/PD-L1 } \\
\text { Antibody }\end{array}$ & $\begin{array}{l}\text { Additional } \\
\text { Treatment }\end{array}$ & Primary Endpoint(s) \\
\hline NCT03472274 & T2-T4a N0-1 M0 & Neoadjuvant & 2 & Durvalumab & Tremelimumab & pCRR \\
\hline NCT02812420 & T2-T3a N0 M0 & Neoadjuvant & 1 & Durvalumab & Tremelimumab & $\mathrm{AE}$ \\
\hline NCT03520491 & T2-T4a N0 M0 & Neoadjuvant & 2 & Nivolumab & Ipilimumab & Patients proceeding to $\mathrm{RC}$ \\
\hline NCT03387761 & $\begin{array}{l}\text { T3-T4a N0 M0 or } \\
\text { T1-4a N1-3 M0 }\end{array}$ & Neoadjuvant & 1 & Nivolumab & Ipilimumab & Patients proceeding to $\mathrm{RC}$ \\
\hline NCT04430036 & T2-T4a N0-1 M0 & Neoadjuvant & 2 & Balstilimab & $\begin{array}{l}\text { Zalifrelimab + } \\
\text { gem/cis }\end{array}$ & pDS to $\mathrm{pT} 0$ \\
\hline NCT04579133 & $\begin{array}{l}\text { T2-T4a N0 M0 or } \\
\text { T1-T4a N1 M0 }\end{array}$ & Neoadjuvant & 2 & Durvalumab & Olaparib & pCRR \\
\hline NCT03534492 & T2-T4a N0 M0 & Neoadjuvant & 2 & Durvalumab & Olaparib & pCRR \\
\hline NCT03832673 & $\begin{array}{c}\text { T2-T3a N0 M0 } \\
\text { TCC }\end{array}$ & Neoadjuvant & 2 & Pembrolizumab & Epacadostat & pCRR \\
\hline NCT02845323 & T2-T4a N0-N2 M0 & Neoadjuvant & 2 & Nivolumab & Urelumab & CD8 density \\
\hline NCT04209114 & T2-T4a N0 M0 & $\begin{array}{l}\text { Neoadjuvant }+ \\
\text { adjuvant }\end{array}$ & 3 & Nivolumab & Bempeg & pCRR, EFS \\
\hline NCT03924895 & $\begin{array}{l}\text { T2-T4a N0 M0 or } \\
\text { T1-T4aN1M0 }\end{array}$ & Neoadjuvant & 3 & Pembrolizumab & $\begin{array}{l}\text { Enfortumab } \\
\text { vedotin }\end{array}$ & pCRR, EFS \\
\hline NCT03258593 & $\begin{array}{c}\text { BCG- } \\
\text { unresponsive }\end{array}$ & Neoadjuvant & 1 & Durvalumab & Vicinium & $\mathrm{AE}$ \\
\hline NCT03978624 & T2-T4a N0-x M0 & Neoadjuvant & 2 & Pembrolizumab & Entinostat & $\begin{array}{l}\text { Change in CD8 immune } \\
\text { signature }\end{array}$ \\
\hline NCT03773666 & T2-T4a N0 M0 & Neoadjuvant & 1 & Durvalumab & Oleclumab & $\begin{array}{l}\text { Patients receiving a single } \\
\text { dose followed by surgery }\end{array}$ \\
\hline NCT03532451 & T2-T4a N0-1 M0 & Neoadjuvant & 1B & Nivolumab & Lirilumab & $\mathrm{AE}$ \\
\hline
\end{tabular}

$\mathrm{AE}=$ adverse events, $\mathrm{DFS}=$ disease free survival, $\mathrm{DLT}=$ dose limiting toxicity, $\mathrm{EFS}=$ event-free survival, $\mathrm{pCRR}=$ pathological complete response rate, $R R=$ response rate.

\subsection{Enhancing Anti-PD-1/PD-L1 Treatment with Targeted Therapies}

Poly (ADP-ribose) polymerase (PARP) is involved in DDR. PARP inhibitors are synthetically lethal against tumors with BRCA1/2 mutations, as these cancer cells are the result of genomic instability [86]. Secondly, PARP inhibitor induced genomic instability leads to more somatic mutations and a higher TMB, which in turn may increase the neoantigen load and immunogenicity, which can be exploited using ICI (Figure 2C) [87,88]. In mice, PARP increased expression of PD-L1, while dual blockade of both PARP and PD-L1 may lead to synergistic effects and increased tumor cell death [89]. In a Phase II study in MIBC, combined inhibition of PARP with olaparib and anti-PD-L1 resulted in a systemic immune response demonstrated by release of chemokines, TNF- $\alpha$, angiogenic factors, tumor infil- 
trating lymphocytes (TIL) and increased IFN-y expression [90]. Preliminary results showed a pCR of $44.5 \%(n=28)$ after treatment with anti-PDL1 and olaparib [91].

TGF- $\beta$ is overexpressed in many malignancies and has long been implicated as a stimulator of cancer progression by regulation of apoptosis, cell proliferation and initiation of epithelial mesenchymal transition (EMT) [92]. An RNA-based TGF- $\beta$ signature was associated with non-response to anti-PD-1 therapy in locally advanced BC and anti-PD-L1 therapy in metastatic BC $[84,93]$. Murine models showed that blocking of TGF- $\beta$ reduces TGF- $\beta$ signaling in stromal cells, facilitated T-cell penetration and provoked strong antitumor immunity and tumor regression [93]. Interestingly, a bi-functional fusion protein (Bintrafusp- $\alpha$ ) targeting anti-PD-L1 and TGF- $\beta$ has recently been developed, and it is expected to be tested in localized BC [94]. Vascular endothelial growth factor (VEGF) impairs hematopoietic differentiation and like TGF- $\beta$ causes an immunosuppressive microenvironment in BC, thereby facilitating evasion of the immune response [95]. Anti-VEGF therapy may eliminate immunosuppressive effects, decreases tumor vasculature, and increases perfusion and influx of T cells [96]. Several trials tested anti-VEGF with concurrent chemotherapy, but this did not result in improved clinical outcome for metastatic BC patients [97]. Thus far, no trials have reported on ICI combinations with anti-VEGF in localized BC yet, but in other cancer entities synergistic effects have been identified [98]. The collagen discoidin domain receptor (DDR2), a kinase, is recognized as a metastases promoter [88]. DDR2 depletion increases sensitivity to anti-PD-1 treatment in vivo in BC and multiple other murine models of cancer [99]. Treatment with the anti-tyrosine kinase inhibitor dasatinib (anti-DDR2) and anti-PD-1 resulted in increased CD8+ tumor lymphocytes compared to monotherapy and a reduced tumor load [99]. Thus, a combination treatment of ICI with dasatinib appears to be worth exploring in localized BC. In summary, the synergistic mechanisms of anti-TGF- $\beta$, anti-VEGF and anti-DDR2 with PD-1/PD-L1 blockade are depicted in Figure 2D.

Finally, Toll-like receptor (TLR) agonists are being investigated in localized BC. Treatment with BCG in vitro triggers TLRs and prevents deprivation of MHC-II expression, thereby promoting immunogenicity $[100,101]$. Treatment with the TLR-4 agonist tasquinimod had weak anti-tumorigenic effects in AY-27 rats and MBT-2 mice models [102]. Combination treatment was tested only in mice, but anti-PD-L1 modulated M1/M2 tumorinfiltrating myeloid cells and increased activity and proliferation of CD8+ T-cells were observed, resulting in tumor regression [102]. To summarize, targeted therapies seem promising when combined with anti-PD-1/PD-L1 treatment, though clinical studies are now needed to assess whether these combination strategies truly enhance clinical efficacy of ICI. An overview of currently ongoing combination trials using targeted treatment combinations with PD-1/PD-L1 blockade are included in Table 2.

\section{Future Directions on PD-1/PD-L1 ICI in Localized BC}

The logical next step to improve efficacy of PD-1/PD-L1 inhibition is by addition of conventional treatments such as $\mathrm{PBC}$ and radiotherapy. Yet for combination strategies, many questions remain open. For instance, on dosage and timing: do we provide PD-1/PD-L1 blockade only as a neoadjuvant treatment or also as a maintenance treatment? Additionally, do we use treatment combinations concurrently or sequentially? Improved overall response rate in metastatic bladder cancer patients treated with maintenance avelumab after cisplatin are inspiring for such an approach in localized BC [103]. Furthermore, maintenance ICI might be beneficial after NAC or BCG.

Since molecular characterization of BCG-unresponsive patients is evolving, the optimal ICI combinations with targeted treatments have yet to be elucidated. However, for BCG-unresponsive HR-NMIBC patients, it appears that PD-1/PD-L1 ICI with other checkpoint inhibitors, such as CTLA-4 inhibitors, are a promising way forward. For novel checkpoint inhibitors, however, more pre-clinical research should be advocated. It is also worthwhile to explore the efficacy and toxicity of ICI when used intravesically in HR-NMIBC to determine if it maintains the therapeutic benefit seen with systemic admin- 
istration [104]. There is no doubt that PD-1/PD-L1 blockade is effective in bladder cancer, and improved biomarker-based selection of patients with the potential for maximum benefit will further improve management while minimizing toxicity and financial costs.

Author Contributions: Conceptualization, F.C.d.J., and D.T.; methodology, F.C.d.J., V.C.R.; formal analysis, F.C.d.J. and V.C.R.; investigation, V.C.R. and F.C.d.J.; resources, T.C.M.Z. and D.T.; data curation, none; writing — original draft preparation, F.C.d.J. and V.C.R.; writing—review and editing, F.C.d.J., T.C.M.Z. and D.T.; supervision, T.C.M.Z. and D.T.; project administration, T.C.M.Z. and D.T.; funding acquisition, none. All authors have read and agreed to the published version of the manuscript.

Funding: This research was supported by CA143971 to D.T. The APC was funded by D.T.

Conflicts of Interest: None of the contributing authors have any conflict of interest, including specific financial interests and relationships and affiliations relevant to the subject matter in the manuscript.

$\begin{array}{ll}\text { Abbreviations } \\ & \\ \text { APC } & \text { antigen presenting cells } \\ \text { BC } & \text { bladder cancer } \\ \text { BCG } & \text { Bacillus Calmette-Guérin } \\ \text { CTLA-4 } & \text { cytotoxic T lymphocyte associated protein } 4 \\ \text { DC } & \text { dendritic cell } \\ \text { DDR } & \text { DNA damage and response } \\ \text { DDR2 } & \text { discoidin domain receptor tyrosine kinase 2 } \\ \text { EMT } & \text { epithelial mesenchymal transition } \\ \text { FAP } & \text { fibroblast activation protein } \\ \text { HR-NMIBC } & \text { high-risk non-muscle invasive bladder cancer } \\ \text { ICI } & \text { immune checkpoint inhibitor } \\ \text { IFN- } \gamma & \text { interferon- } \gamma \\ \text { IHC } & \text { immunohistochemistry } \\ \text { LAG-3 } & \text { lymphocyte activation gene-3 } \\ \text { MDSC } & \text { myeloid derived suppressor cell } \\ \text { MHC-1 } & \text { major histocompatibility complex I } \\ \text { MIBC } & \text { muscle-invasive bladder cancer } \\ \text { NAC } & \text { neoadjuvant chemotherapy } \\ \text { NK } & \text { natural killer cell } \\ \text { NMIBC } & \text { non-muscle invasive bladder cancer } \\ \text { OS } & \text { overall survival } \\ \text { PARP } & \text { poly ADP-ribose polymerase } \\ \text { PBC } & \text { platinum-based chemotherapy } \\ \text { pCR } & \text { pathological complete response } \\ \text { PD-1 } & \text { programmed cell death protein 1 } \\ \text { PD-L1 } & \text { programmed death-ligand 1 } \\ \text { PFS } & \text { progression-free survival } \\ \text { PLND } & \text { pelvic lymph node dissection } \\ \text { RB1 } & \text { retinoblastoma protein 1 } \\ \text { RC } & \text { radical cystectomy } \\ \text { RFS } & \text { recurrence-free survival } \\ \text { ROS } & \text { reactive oxygen species } \\ \text { STAT6 } & \text { signal transducer and activator of transcription } 6 \\ \text { TGF- } \beta & \text { transforming growth factor beta } \\ \text { TIGIT } & \text { T cell immunoglobulin and ITIM domain } \\ \text { TMB } & \text { tumor mutational burden } \\ \text { TME } & \text { transurethral resection of bladder tumor } \\ \text { TURBT } & \text { vascular endothelial growth factor } \\ \text { VEGF } & \end{array}$




\section{References}

1. Richters, A.; Aben, K.K.H.; Kiemeney, L.A.L.M. The global burden of urinary bladder cancer: An update. World J. Urol. 2020, 38, 1895-1904. [CrossRef] [PubMed]

2. Witjes, J.A.; Bruins, H.M.; Cathomas, R.; Compérat, E.; Cowan, N.C.; Gakies, G.; Hernández, V.; Lorch, A.; Ribal, M.J.; Thalmann, G.N.; et al. Eau Guidelines on Muscle Invasive and Metastatic Bladder Cancer. In Proceedings of the EAU Annual Congress Barcelona, Barcelona, Spain, 17-21 July 2020.

3. Tran, L.; Xiao, J.; Agarwal, N.; Duex, J.E.; Theodorescu, D. Scientific Advances Transforming Bladder Cancer Care. Nat. Rev. Cancer 2020, in press.

4. Malmström, P.-U.; Sylvester, R.J.; Crawford, D.E.; Friedrich, M.; Krege, S.; Rintala, E.; Solsona, E.; Di Stasi, S.M.; Witjes, J.A. An Individual Patient Data Meta-Analysis of the Long-Term Outcome of Randomised Studies Comparing Intravesical Mitomycin C versus Bacillus Calmette-Guérin for Non-Muscle-Invasive Bladder Cancer. Eur. Urol. 2009, 56, 247-256. [CrossRef] [PubMed]

5. Witjes, J.A. Management of BCG Failures in Superficial Bladder Cancer: A Review. Eur. Urol. 2006, 49, 790-797. [CrossRef] [PubMed]

6. $\quad$ de Jong, F.C.; Hoedemaeker, R.F.; Kvikstad, V.; Mensink, J.T.M.; de Jong, J.J.; Boevé, E.R.; van der Schoot, D.K.E.; Zwarthoff, E.C.; Boormans, J.L.; Zuiverloon, T.C.M. T1-Substaging of Non-Muscle Invasive Bladder Cancer Is Associated with BCG-Failure and Improves Patient Stratification at Diagnosis. J. Urol. 2020, 205, 701-708. [CrossRef]

7. Li, R.; Tabayoyong, W.B.; Guo, C.C.; González, G.M.N.; Navai, N.; Grossman, H.B.; Dinney, C.P.; Kamat, A.M. Prognostic Implication of the United States Food and Drug Administration-defined BCG-unresponsive Disease. Eur. Urol. 2019, 75, 8-10. [CrossRef]

8. Aziz, A.; May, M.; Burger, M.; Palisaar, R.-J.; Trinh, Q.-D.; Fritsche, H.-M.; Rink, M.; Chun, F.; Martini, T.; Bolenz, C.; et al. Prediction of 90-day Mortality After Radical Cystectomy for Bladder Cancer in a Prospective European Multicenter Cohort. Eur. Urol. 2014, 66, 156-163. [CrossRef] [PubMed]

9. Stein, J.P.; Skinner, D.G. Radical cystectomy for invasive bladder cancer: Long-term results of a standard procedure. World J. Urol. 2006, 24, 296-304. [CrossRef] [PubMed]

10. James, N.D.; Hussain, S.A.; Hall, E.; Jenkins, P.; Tremlett, J.; Rawlings, C.; Crundwell, M.; Sizer, B.; Sreenivasan, T.; Hendron, C.; et al. Radiotherapy with or without Chemotherapy in Muscle-Invasive Bladder Cancer. N. Engl. J. Med. 2012, 366, 1477-1488. [CrossRef]

11. Daro-Faye, M.; Kassouf, W.; Souhami, L.; Marcq, G.; Cury, F.; Niazi, T.; Sargos, P. Combined radiotherapy and immunotherapy in urothelial bladder cancer: Harnessing the full potential of the anti-tumor immune response. World J. Urol. 2020, 1-13. [CrossRef]

12. Hahn, N.M.; Necchi, A.; Loriot, Y.; Powles, T.; Plimack, E.R.; Sonpavde, G.; Roupret, M.; Kamat, A.M. Role of Checkpoint Inhibition in Localized Bladder Cancer. Eur. Urol. Oncol. 2018, 1, 190-198. [CrossRef] [PubMed]

13. Rouanne, M.; Bajorin, D.F.; Hannan, R.; Galsky, M.D.; Williams, S.B.; Necchi, A.; Sharma, P.; Powles, T. Rationale and Outcomes for Neoadjuvant Immunotherapy in Urothelial Carcinoma of the Bladder. Eur. Urol. Oncol. 2020, 3, 728-738. [CrossRef]

14. Sharpe, A.H.; Pauken, K.E. The diverse functions of the PD1 inhibitory pathway. Nat. Rev. Immunol. 2018, 18, 153-167. [CrossRef] [PubMed]

15. Waldman, A.D.; Fritz, J.M.; Lenardo, M.J. A guide to cancer immunotherapy: From T cell basic science to clinical practice. Nat. Rev. Immunol. 2020, 20, 651-668. [CrossRef]

16. Keir, M.E.; Butte, M.J.; Freeman, G.J.; Sharpe, A.H. PD-1 and Its Ligands in Tolerance and Immunity. Annu. Rev. Immunol. 2008, 26, 677-704. [CrossRef] [PubMed]

17. Pardoll, D.M. The blockade of immune checkpoints in cancer immunotherapy. Nat. Rev. Cancer 2012, 12, 252-264. [CrossRef] [PubMed]

18. Vandeveer, A.J.; Fallon, J.K.; Tighe, R.; Sabzevari, H.; Schlom, J.; Greiner, J.W. Systemic Immunotherapy of Non-Muscle Invasive Mouse Bladder Cancer with Avelumab, an Anti-PD-L1 Immune Checkpoint Inhibitor. Cancer Immunol. Res. 2016, 4, 452-462. [CrossRef]

19. Wang, Y.; Liu, J.; Yang, X.; Liu, Y.; Liu, Y.; Li, Y.; Sun, L.; Yang, X.; Niu, H. Bacillus Calmette-Guérin and anti-PD-L1 combination therapy boosts immune response against bladder cancer. OncoTargets Ther. 2018, ume 11, 2891-2899. [CrossRef]

20. Zhou, T.C.; Sankin, A.I.; Porcelli, S.A.; Perlin, D.S.; Schoenberg, M.P.; Zang, X. A review of the PD-1/PD-L1 checkpoint in bladder cancer: From mediator of immune escape to target for treatment. Urol. Oncol. Semin. Orig. Investig. 2017, 35, 14-20. [CrossRef]

21. Boorjian, S.A.; Sheinin, Y.; Crispen, P.L.; Farmer, S.A.; Lohse, C.M.; Kuntz, S.M.; Leibovich, B.C.; Kwon, E.D.; Frank, I. T-Cell Coregulatory Molecule Expression in Urothelial Cell Carcinoma: Clinicopathologic Correlations and Association with Survival. Clin. Cancer Res. 2008, 14, 4800-4808. [CrossRef]

22. Inman, B.A.; Sebo, T.J.; Frigola, X.; Dong, H.; Bergstralh, E.J.; Fradet, Y.; Lacombe, L.; Kwon, E.D. PD-L1 (B7-H1) Expression by Urothelial Carcinoma of the Bladder and BCG-Induced Granulomata: Associations with Localized Stage Progression. Cancer 2007, 109, 1499-1505. [CrossRef] [PubMed]

23. Ding, X.; Chen, Q.; Yang, Z.; Li, J.; Zhan, H.; Lu, N.; Chen, M.; Yang, Y.; Wang, J.; Yang, D. Clinicopathological and prognostic value of PD-L1 in urothelial carcinoma: A meta-analysis. Cancer Manag. Res. 2019, 11, 4171-4184. [CrossRef] [PubMed]

24. Kates, M.; Matoso, A.; Choi, W.; Baras, A.S.; Daniels, M.J.; Lombardo, K.; Brant, A.; Mikkilineni, N.; McConkey, D.J.; Kamat, A.M.; et al. Adaptive Immune Resistance to Intravesical BCG in Non-Muscle Invasive Bladder Cancer: Implications for Prospective BCG-Unresponsive Trials. Clin. Cancer Res. 2020, 26, 882-891. [CrossRef] [PubMed] 
25. Pierconti, F.; Raspollini, M.R.; Martini, M.; Larocca, L.M.; Bassi, P.F.; Bientinesi, R.; Baroni, G.; Minervini, A.; Petracco, G.; Pini, G.M.; et al. PD-L1 Expression in Bladder Primary in Situ Urothelial Carcinoma: Evaluation in BCG-Unresponsive Patients and BCG Responders. Virchows Arch. 2020, 477, 269-277. [CrossRef]

26. Aydin, A.M.; Baydar, D.E.; Hazir, B.; Babaoglu, B.; Bilen, C.Y. Prognostic significance of pre- and post-treatment PD-L1 expression in patients with primary high-grade non-muscle-invasive bladder cancer treated with BCG immunotherapy. World J. Urol. 2020, 38, 2537-2545. [CrossRef]

27. Tu, M.M.; Ng, T.L.; de Jong, F.C.; Zuiverloon, T.C.M.; Fazzari, F.G.T.; Theodorescu, D. Molecular Biomarkers of Response to PD-1/ PD-L1 Immune Checkpoint Blockade in Advanced Bladder Cancer. Bladder Cancer 2019, 5, 131-145. [CrossRef] [PubMed]

28. Tan, W.P.; Tan, W.S.; Inman, B.A. PD-L1/PD-1 Biomarker for Metastatic Urothelial Cancer that Progress Post-platinum Therapy: A Systematic Review and Meta-analysis. Bladder Cancer 2019, 5, 211-223. [CrossRef]

29. Lavoie, J.-M.; Black, P.C.; Eigl, B.J. Predictive Biomarkers for Checkpoint Blockade in Urothelial Cancer: A Systematic Review. J. Urol. 2019, 202, 49-56. [CrossRef]

30. Balar, A.V.; Kamat, A.M.; Kulkarni, G.S.; Uchio, E.M.; Boormans, J.L.; Bajorin, D.F.; Roumiguié, M.; Singer, E.A.; Krieger, L.E.M.; Grivas, P.; et al. Pembrolizumab (pembro) for the treatment of patients with Bacillus Calmette-Guérin (BCG) unresponsive, high-risk (HR) non-muscle-invasive bladder cancer (NMIBC): Over two years follow-up of KEYNOTE-057. J. Clin. Oncol. 2020, 38, 5041. [CrossRef]

31. Gust, K.M.; Rebhan, K.; Resch, I.; Shariat, S.F.; Necchi, A. Immune checkpoint inhibition in muscle-invasive and locally advanced bladder cancer. Curr. Opin. Urol. 2020, 30, 547-556. [CrossRef]

32. Necchi, A.; Raggi, D.; Gallina, A.; Madison, R.; Colecchia, M.; Lucianò, R.; Montironi, R.; Giannatempo, P.; Farè, E.; Pederzoli, F.; et al. Updated Results of PURE-01 with Preliminary Activity of Neoadjuvant Pembrolizumab in Patients with Muscle-invasive Bladder Carcinoma with Variant Histologies. Eur. Urol. 2020, 77, 439-446. [CrossRef]

33. Powles, T.; Kockx, M.; Rodriguez-Vida, A.; Duran, I.; Crabb, S.J.; Van Der Heijden, M.S.; Szabados, B.; Pous, A.F.; Gravis, G.; Herranz, U.A.; et al. Clinical efficacy and biomarker analysis of neoadjuvant atezolizumab in operable urothelial carcinoma in the ABACUS trial. Nat. Med. 2019, 25, 1706-1714. [CrossRef]

34. Bandini, M.; Gibb, E.; Gallina, A.; Raggi, D.; Marandino, L.; Bianchi, M.; Ross, J.; Colecchia, M.; Gandaglia, G.; Fossati, N.; et al. Does the administration of preoperative pembrolizumab lead to sustained remission post-cystectomy? First survival outcomes from the PURE-01 study. Ann. Oncol. 2020, 31, 1755-1763. [CrossRef]

35. Necchi, A.; Anichini, A.; Raggi, D.; Briganti, A.; Massa, S.; Lucianò, R.; Colecchia, M.; Giannatempo, P.; Mortarini, R.; Bianchi, M.; et al. Pembrolizumab as Neoadjuvant Therapy Before Radical Cystectomy in Patients with Muscle-Invasive Urothelial Bladder Carcinoma (PURE-01): An Open-Label, Single-Arm, Phase II Study. J. Clin. Oncol. 2018, 36, 3353-3360. [CrossRef]

36. Hato, S.V.; Khong, A.; De Vries, I.J.M.; Lesterhuis, W.J. Molecular Pathways: The Immunogenic Effects of Platinum-Based Chemotherapeutics. Clin. Cancer Res. 2014, 20, 2831-2837. [CrossRef]

37. Emens, L.A.; Middleton, G. The Interplay of Immunotherapy and Chemotherapy: Harnessing Potential Synergies. Cancer Immunol. Res. 2015, 3, 436-443. [CrossRef] [PubMed]

38. Grimaldi, A.; Cammarata, I.; Martire, C.; Focaccetti, C.; Piconese, S.; Buccilli, M.; Mancone, C.; Buzzacchino, F.; Berrios, J.R.G.; D'Alessandris, N.; et al. Combination of chemotherapy and PD-1 blockade induces T cell responses to tumor non-mutated neoantigens. Commun. Biol. 2020, 3, 1-13. [CrossRef]

39. Grabosch, S.; Bulatovic, M.; Zeng, F.; Ma, T.; Zhang, L.; Ross, M.; Brozick, J.; Fang, Y.; Tseng, G.; Kim, E.; et al. Cisplatininduced immune modulation in ovarian cancer mouse models with distinct inflammation profiles. Oncogene 2019, 38, $2380-2393$. [CrossRef]

40. Ohtsukasa, S.; Okabe, S.; Yamashita, H.; Iwai, T.; Sugihara, K. Increased expression of CEA and MHC class I in colorectal cancer cell lines exposed to chemotherapy drugs. J. Cancer Res. Clin. Oncol. 2003, 129, 719-726. [CrossRef] [PubMed]

41. Shurin, G.V.; Tourkova, I.L.; Kaneno, R.; Shurin, M.R. Chemotherapeutic Agents in Noncytotoxic Concentrations Increase Antigen Presentation by Dendritic Cells via an IL-12-Dependent Mechanism. J. Immunol. 2009, 183, 137-144. [CrossRef]

42. Beyranvand Nejad, E.; van der Sluis, T.C.; van Duikeren, S.; Yagita, H.; Janssen, G.M.; van Veelen, P.A.; Melief, C.J.; van der Burg, S.H.; Arens, R. Tumor Eradication by Cisplatin Is Sustained by Cd80/86-Mediated Costimulation of Cd8+ T Cells. Cancer Res. 2016, 76, 6017-6029. [CrossRef] [PubMed]

43. Li, S.; Ji, J.; Zhang, Z.; Peng, Q.; Hao, L.; Guo, Y.; Zhou, W.; Cui, Q.; Shi, X. Cisplatin promotes the expression level of PD-L1 in the microenvironment of hepatocellular carcinoma through YAP1. Mol. Cell. Biochem. 2020, 475, 79-91. [CrossRef]

44. Tran, L.; Allen, C.T.; Xiao, R.; Moore, E.; Davis, R.; Park, S.-J.; Spielbauer, K.; Van Waes, C.; Schmitt, N.C. Cisplatin Alters Antitumor Immunity and Synergizes with PD-1/PD-L1 Inhibition in Head and Neck Squamous Cell Carcinoma. Cancer Immunol. Res. 2017, 5, 1141-1151. [CrossRef] [PubMed]

45. Tsai, T.-F.; Lin, J.-F.; Lin, Y.-C.; Chou, K.-Y.; Chen, H.-E.; Ho, C.-Y.; Chen, P.-C.; Sheng Hwang, T.I. Cisplatin Contributes to Programmed Death-Ligand 1 Expression in Bladder Cancer through Erk1/2-Ap-1 Signaling Pathway. Biosci. Rep. 2019, 39, BSR20190362. [CrossRef] [PubMed]

46. Ghiotto, M.; Gauthier, L.; Serriari, N.; Pastor, S.; Truneh, A.; Nunès, J.A.; Olive, D. PD-L1 and PD-L2 differ in their molecular mechanisms of interaction with PD-1. Int. Immunol. 2010, 22, 651-660. [CrossRef] 
47. Lesterhuis, W.J.; Punt, C.J.A.; Hato, S.V.; Eleveld-Trancikova, D.; Jansen, B.J.H.; Nierkens, S.; Schreibelt, G.; De Boer, A.; Van Herpen, C.M.L.; Kaanders, J.H.; et al. Platinum-based drugs disrupt STAT6-mediated suppression of immune responses against cancer in humans and mice. J. Clin. Investig. 2011, 121, 3100-3108. [CrossRef] [PubMed]

48. Xue, Y.; Gao, S.; Gou, J.; Yin, T.; He, H.; Wang, Y.; Zhang, Y.; Tang, X.; Wu, R. Platinum-based chemotherapy in combination with PD-1/PD-L1 inhibitors: Preclinical and clinical studies and mechanism of action. Expert Opin. Drug Deliv. 2021, 18, 187-203. [CrossRef] [PubMed]

49. Grasselly, C.; Denis, M.; Bourguignon, A.; Talhi, N.; Mathe, D.; Tourette, A.; Serre, L.; Jordheim, L.P.; Matera, E.L.; Dumontet, C. The Antitumor Activity of Combinations of Cytotoxic Chemotherapy and Immune Checkpoint Inhibitors Is Model-Dependent. Front. Immunol. 2018, 9, 2100. [CrossRef]

50. Kaimakliotis, H.; Albany, C.; Hoffman-Censits, J.; Trabulsi, E.; Kelly, W.K.; Picus, J.; Adra, N.; Cary, C.; Koch, M.; Fleming, M.; et al. PD52-03 a multicenter phase 1B/2 study of neoadjuvant pembrolizumab and cisplatin chemotherapy for muscle invasive urothelial cancer. J. Urol. 2019, 201, 924. [CrossRef]

51. Gupta, S.; Sonpavde, G.; Weight, C.J.; McGregor, B.A.; Gupta, S.; Maughan, B.L.; Wei, X.X.; Gibb, E.; Thyagarajan, B.; Einstein, D.J.; et al. Results from BLASST-1 (Bladder Cancer Signal Seeking Trial) of nivolumab, gemcitabine, and cisplatin in muscle invasive bladder cancer (MIBC) undergoing cystectomy. J. Clin. Oncol. 2020, 38, 439. [CrossRef]

52. Kaimakliotis, H.Z.; Adra, N.; Kelly, W.K.; Trabulsi, E.J.; Lauer, R.C.; Picus, J.; Smith, Z.L.; Walling, R.; Masterson, T.A.; Calaway, A.C.; et al. Phase II neoadjuvant (N-) gemcitabine $(\mathrm{G})$ and pembrolizumab (P) for locally advanced urothelial cancer (laUC): Interim results from the cisplatin (C)-ineligible cohort of GU14-188. J. Clin. Oncol. 2020, 38, 5019. [CrossRef]

53. Cathomas, R.; Petrausch, U.; Hayoz, S.; Schneider, M.; Schardt, J.A.; Seiler, R.; Erdmann, A.; Rothschild, S.; Aeppli, S.; Mach, N.; et al. Perioperative Chemoimmunotherapy with Durvalumab (Durva) in Combination with Cisplatin/Gemcitabine (Cis/Gem) for Operable Muscle-Invasive Urothelial Carcinoma (Miuc): Preplanned Interim Analysis of a Single-Arm Phase Ii Trial (Sakk 06/17). J. Clin. Oncol. 2020, 38, 499. [CrossRef]

54. Iliakis, G.; Wang, Y.; Guan, J.; Wang, H. DNA damage checkpoint control in cells exposed to ionizing radiation. Oncogene 2003, 22, 5834-5847. [CrossRef] [PubMed]

55. Mikkelsen, R.B.; Wardman, P. Biological chemistry of reactive oxygen and nitrogen and radiation-induced signal transduction mechanisms. Oncogene 2003, 22, 5734-5754. [CrossRef]

56. Burnette, B.C.; Liang, H.; Lee, Y.; Chlewicki, L.; Khodarev, N.N.; Weichselbaum, R.R.; Fu, Y.-X.; Auh, S.L. The Efficacy of Radiotherapy Relies upon Induction of Type I Interferon-Dependent Innate and Adaptive Immunity. Cancer Res. 2011, 71, 2488-2496. [CrossRef] [PubMed]

57. Fuertes, M.B.; Kacha, A.K.; Kline, J.; Woo, S.-R.; Kranz, D.M.; Murphy, K.M.; Gajewski, T.F. Host type I IFN signals are required for antitumor CD8+ T cell responses through CD8 $\alpha+$ dendritic cells. J. Exp. Med. 2011, 208, 2005-2016. [CrossRef] [PubMed]

58. Lugade, A.A.; Moran, J.P.; Gerber, S.A.; Rose, R.C.; Frelinger, J.G.; Lord, E.M. Local Radiation Therapy of B16 Melanoma Tumors Increases the Generation of Tumor Antigen-Specific Effector Cells That Traffic to the Tumor. J. Immunol. 2005, 174, 7516-7523. [CrossRef]

59. Weichselbaum, R.R.; Liang, H.; Deng, L.; Fu, Y.-X. Radiotherapy and immunotherapy: A beneficial liaison? Nat. Rev. Clin. Oncol. 2017, 14, 365-379. [CrossRef] [PubMed]

60. Formenti, S.C.; DeMaria, S. Combining Radiotherapy and Cancer Immunotherapy: A Paradigm Shift. J. Natl. Cancer Inst. 2013, 105, 256-265. [CrossRef]

61. Reits, E.A.; Hodge, J.W.; Herberts, C.A.; Groothuis, T.A.; Chakraborty, M.; Wansley, E.K.; Camphausen, K.; Luiten, R.M.; De Ru, A.H.; Neijssen, J.; et al. Radiation modulates the peptide repertoire, enhances MHC class I expression, and induces successful antitumor immunotherapy. J. Exp. Med. 2006, 203, 1259-1271. [CrossRef]

62. Gasser, S.; Orsulic, S.; Brown, E.J.; Raulet, D.H. The DNA damage pathway regulates innate immune system ligands of the NKG2D receptor. Nature 2005, 436, 1186-1190. [CrossRef]

63. Chiang, C.-S.; Fu, S.Y.; Wang, S.-C.; Yu, C.-F.; Chen, F.-H.; Lin, C.-M.; Hong, J.-H. Irradiation Promotes an M2 Macrophage Phenotype in Tumor Hypoxia. Front. Oncol. 2012, 2, 89. [CrossRef]

64. Bunt, S.K.; Yang, L.; Sinha, P.; Clements, V.K.; Leips, J.; Ostrand-Rosenberg, S. Reduced Inflammation in the Tumor Microenvironment Delays the Accumulation of Myeloid-Derived Suppressor Cells and Limits Tumor Progression. Cancer Res. 2007, 67, 10019-10026. [CrossRef] [PubMed]

65. Vanpouille-Box, C.; Diamond, J.M.; Pilones, K.A.; Zavadil, J.; Babb, J.S.; Formenti, S.C.; Barcellos-Hoff, M.H.; DeMaria, S. TGF $\beta$ Is a Master Regulator of Radiation Therapy-Induced Antitumor Immunity. Cancer Res. 2015, 75, 2232-2242. [CrossRef]

66. Victor, C.T.-S.; Rech, A.J.; Maity, A.; Rengan, R.; Pauken, K.E.; Stelekati, E.; Benci, J.L.; Xu, B.; Dada, H.; Odorizzi, P.M.; et al. Radiation and dual checkpoint blockade activate non-redundant immune mechanisms in cancer. Nature 2015, 520, 373-377. [CrossRef]

67. Derer, A.; Frey, B.; Fietkau, R.; Gaipl, U.S. Immune-modulating properties of ionizing radiation: Rationale for the treatment of cancer by combination radiotherapy and immune checkpoint inhibitors. Cancer Immunol. Immunother. 2016, 65, 779-786. [CrossRef] [PubMed]

68. Deng, L.; Liang, H.; Burnette, B.; Beckett, M.; Darga, T.; Weichselbaum, R.R.; Fu, Y.-X. Irradiation and anti-PD-L1 treatment synergistically promote antitumor immunity in mice. J. Clin. Investig. 2014, 124, 687-695. [CrossRef] [PubMed] 
69. Sharabi, A.B.; Nirschl, C.J.; Kochel, C.M.; Nirschl, T.R.; Francisca, B.J.; Velarde, E.; Deweese, T.L.; Drake, C.G. Stereotactic Radiation Therapy Augments Antigen-Specific PD-1-Mediated Antitumor Immune Responses via Cross-Presentation of Tumor Antigen. Cancer Immunol. Res. 2015, 3, 345-355. [CrossRef] [PubMed]

70. Wu, C.-T.; Chen, W.-C.; Chang, Y.-H.; Lin, W.-Y.; Chen, M.-F. The role of PD-L1 in the radiation response and clinical outcome for bladder cancer. Sci. Rep. 2016, 6, 19740. [CrossRef]

71. Liu, Y.; Dong, Y.; Kong, L.; Shi, F.; Zhu, H.; Yu, J. Abscopal effect of radiotherapy combined with immune checkpoint inhibitors. J. Hematol. Oncol. 2018, 11, 1-15. [CrossRef]

72. Park, S.S.; Dong, H.; Liu, X.; Harrington, S.M.; Krco, C.J.; Grams, M.P.; Mansfield, A.S.; Furutani, K.M.; Olivier, K.R.; Kwon, E.D. PD-1 Restrains Radiotherapy-Induced Abscopal Effect. Cancer Immunol. Res. 2015, 3, 610-619. [CrossRef]

73. Solanki, A.A.; Bossi, A.; Efstathiou, J.A.; Lock, D.; Mondini, M.; Ramapriyan, R.; Welsh, J.; Kang, J. Combining Immunotherapy with Radiotherapy for the Treatment of Genitourinary Malignancies. Eur. Urol. Oncol. 2019, 2, 79-87. [CrossRef]

74. Walshaw, R.C.; Honeychurch, J.; Illidge, T.M.; Choudhury, A. The anti-PD-1 era-An opportunity to enhance radiotherapy for patients with bladder cancer. Nat. Rev. Urol. 2018, 15, 251-259. [CrossRef]

75. Tholomier, C.; Marcq, G.; Shinde-Jadhav, S.; Ayoub, M.; Huang, J.M.; Kool, R.; Skowronski, R.; Brimo, F.; Mansure, J.J.; Kassouf, W. Optimizing Sequence of PD-L1 Immune-Checkpoint Inhibitors and Radiation Therapy in Bladder Cancer. Bladder Cancer 2020, 6, 295-302. [CrossRef]

76. Alegre, M.-L.; Frauwirth, K.A.; Thompson, C.B. T-cell regulation by CD28 and CTLA-4. Nat. Rev. Immunol. 2001, 1, 220-228. [CrossRef] [PubMed]

77. Buchbinder, E.I.; Desai, A. CTLA-4 and PD-1 Pathways: Similarities, Differences, and Implications of Their Inhibition. Am. J. Clin. Oncol. 2016, 39, 98-106. [CrossRef] [PubMed]

78. Webb, E.S.; Liu, P.; Baleeiro, R.; Lemoine, N.R.; Yuan, M.; Wang, Y.-H. Immune checkpoint inhibitors in cancer therapy. J. Biomed. Res. 2018, 32, 317-326. [CrossRef] [PubMed]

79. Curran, M.A.; Montalvo, W.; Yagita, H.; Allison, J.P. PD-1 and CTLA-4 combination blockade expands infiltrating T cells and reduces regulatory $\mathrm{T}$ and myeloid cells within B16 melanoma tumors. Proc. Natl. Acad. Sci. USA 2010, 107, 4275-4280. [CrossRef]

80. Duraiswamy, J.; Kaluza, K.M.; Freeman, G.J.; Coukos, G. Dual Blockade of PD-1 and CTLA-4 Combined with Tumor Vaccine Effectively Restores T-Cell Rejection Function in Tumors. Cancer Res. 2013, 73, 3591-3603. [CrossRef]

81. Fiegle, E.; Doleschel, D.; Koletnik, S.; Rix, A.; Weiskirchen, R.; Borkham-Kamphorst, E.; Kiessling, F.; Lederle, W. Dual CTLA-4 and PD-L1 Blockade Inhibits Tumor Growth and Liver Metastasis in a Highly Aggressive Orthotopic Mouse Model of Colon Cancer. Neoplasia 2019, 21, 932-944. [CrossRef]

82. Mangsbo, S.M.; Sandin, L.C.; Anger, K.; Korman, A.J.; Loskog, A.; Tötterman, T.H. Enhanced Tumor Eradication by Combining CTLA-4 or PD-1 Blockade with CpG Therapy. J. Immunother. 2010, 33, 225-235. [CrossRef]

83. Van Hooren, L.; Sandin, L.C.; Moskalev, I.; Ellmark, P.; Dimberg, A.; Black, P.; Tötterman, T.H.; Mangsbo, S.M. Local checkpoint inhibition of CTLA-4 as a monotherapy or in combination with anti-PD1 prevents the growth of murine bladder cancer. Eur. J. Immunol. 2017, 47, 385-393. [CrossRef]

84. Van Dijk, N.; Gil-Jimenez, A.; Silina, K.; Hendricksen, K.; Smit, L.A.; De Feijter, J.M.; Van Montfoort, M.L.; Van Rooijen, C.; Peters, D.; Broeks, A.; et al. Preoperative ipilimumab plus nivolumab in locoregionally advanced urothelial cancer: The NABUCCO trial. Nat. Med. 2020, 26, 1839-1844. [CrossRef]

85. Postow, M.; Sidlow, R.; Hellmann, M.D. Immune-Related Adverse Events Associated with Immune Checkpoint Blockade. N. Engl. J. Med. 2018, 378, 158-168. [CrossRef] [PubMed]

86. Farmer, H.; McCabe, N.; Lord, C.J.; Tutt, A.N.J.; Johnson, D.A.; Richardson, T.B.; Santarosa, M.; Dillon, K.J.; Hickson, I.D.; Knights, C.; et al. Targeting the DNA repair defect in BRCA mutant cells as a therapeutic strategy. Nature 2005, 434, 917-921. [CrossRef] [PubMed]

87. Lord, C.J.; Ashworth, A. The DNA damage response and cancer therapy. Nature 2012, 481, 287-294. [CrossRef] [PubMed]

88. Criscuolo, D.; Morra, F.; Giannella, R.; Visconti, R.; Cerrato, A.; Celetti, A. New combinatorial strategies to improve the PARP inhibitors efficacy in the urothelial bladder Cancer treatment. J. Exp. Clin. Cancer Res. 2019, 38, 1-9. [CrossRef] [PubMed]

89. Shiping, J.; Xia, W.; Yamaguchi, H.; Wei, Y.; Chen, M.-K.; Hsu, J.-M.; Hsu, J.L.; Yu, W.-H.; Du, Y.; Lee, H.-H.; et al. Parp Inhibitor Upregulates PD-L1 Expression and Enhances Cancer-Associated Immunosuppression. Clin. Cancer Res. 2017, 23, 3711-3720.

90. Lampert, E.J.; Zimmer, A.S.; Padget, M.R.; Cimino-Mathews, A.; Nair, J.R.; Liu, Y.; Swisher, E.M.; Hodge, J.W.; Nixon, A.B.; Nichols, E.; et al. Combination of PARP Inhibitor Olaparib, and PD-L1 Inhibitor Durvalumab, in Recurrent Ovarian Cancer: A Proof-of-Concept Phase II Study. Clin. Cancer Res. 2020, 26, 4268-4279. [CrossRef] [PubMed]

91. Rodriguez-Moreno, J.F.; de Velasco, G.; Fernandez, I.B.; Alvarez-Fernandez, C.; Fernandez, R.; Vazquez-Estevez, S.; Virizuela, J.A.; Gajate, P.; Font, A.; Lainez, N.; et al. Impact of the Combination of Durvalumab (Medi4736) Plus Olaparib (Azd2281) Administered Prior to Surgery in the Molecular Profile of Resectable Urothelial Bladder Cancer: Neodurvarib Trial. J. Clin. Oncol. 2019, 38, 542. [CrossRef]

92. Pickup, M.W.; Novitskiy, S.V.; Moses, H.L. The roles of TGF $\beta$ in the tumour microenvironment. Nat. Rev. Cancer 2013, 13, 788-799. [CrossRef]

93. Mariathasan, S.; Turley, S.J.; Nickles, D.; Castiglioni, A.; Yuen, K.; Wang, Y.; Kadel, E.E., III; Koeppen, H.; Astarita, J.L.; Cubas, R.; et al. TGF $\beta$ Attenuates Tumour Response to PD-L1 Blockade by Contributing to Exclusion of T Cells. Nature 2018, 554, 544-548. [CrossRef] 
94. Ravi, R.; Noonan, K.A.; Pham, V.; Bedi, R.; Zhavoronkov, A.; Ozerov, I.V.; Makarev, E.; Artemov, A.V.; Wysocki, P.T.; Mehra, R.; et al. Bifunctional immune checkpoint-targeted antibody-ligand traps that simultaneously disable TGF $\beta$ enhance the efficacy of cancer immunotherapy. Nat. Commun. 2018, 9, 1-14. [CrossRef]

95. Ohm, J.E.; Carbone, D.P. VEGF as a Mediator of Tumor-Associated Immunodeficiency. Immunol. Res. 2001, 23, 263-272. [CrossRef]

96. Farsaci, B.; Donahue, R.N.; Coplin, M.A.; Grenga, I.; Lepone, L.M.; Molinolo, A.A.; Hodge, J.W. Immune Consequences of Decreasing Tumor Vasculature with Antiangiogenic Tyrosine Kinase Inhibitors in Combination with Therapeutic Vaccines. Cancer Immunol. Res. 2014, 2, 1090-1102. [CrossRef]

97. Ghafouri, S.; Burkenroad, A.; Pantuck, M.; Almomani, B.; Stefanoudakis, D.; Shen, J.; Drakaki, A. VEGF inhibition in urothelial cancer: The past, present and future. World J. Urol. 2020, 1-9. [CrossRef] [PubMed]

98. Molife, C.; Hess, L.M.; Cui, Z.L.; Li, X.I.; Beyrer, J.; Mahoui, M.; Oton, A.B. Sequential therapy with ramucirumab and/or checkpoint inhibitors for non-small-cell lung cancer in routine practice. Futur. Oncol. 2019, 15, 2915-2931. [CrossRef] [PubMed]

99. Tu, M.M.; Lee, F.Y.F.; Jones, R.T.; Kimball, A.K.; Saravia, E.; Graziano, R.F.; Coleman, B.; Menard, K.; Yan, J.; Michaud, E.; et al. Targeting DDR2 enhances tumor response to anti-PD-1 immunotherapy. Sci. Adv. 2019, 5, eaav2437. [CrossRef] [PubMed]

100. Bakhru, P.; Sirisaengtaksin, N.; Soudani, E.; Mukherjee, S.; Khan, A.; Jagannath, C. BCG vaccine mediated reduction in the MHC-II expression of macrophages and dendritic cells is reversed by activation of Toll-like receptors 7 and 9. Cell. Immunol. 2014, 287, 53-61. [CrossRef] [PubMed]

101. Wang, Y.-H.; Cao, Y.-W.; Yang, X.-C.; Niu, H.-T.; Sun, L.-J.; Wang, X.-S.; Liu, J. Effect of TLR4 and B7-H1 on Immune Escape of Urothelial Bladder Cancer and its Clinical Significance. Asian Pac. J. Cancer Prev. 2014, 15, 1321-1326. [CrossRef] [PubMed]

102. Nakhlé, J.; Pierron, V.; Bauchet, A.-L.; Plas, P.; Thiongane, A.; Meyer-Losic, F.; Schmidlin, F. Tasquinimod modulates tumorinfiltrating myeloid cells and improves the antitumor immune response to PD-L1 blockade in bladder cancer. OncoImmunology 2016, 5, e1145333. [CrossRef] [PubMed]

103. Powles, T.; Park, S.H.; Voog, E.; Caserta, C.; Valderrama, B.P.; Gurney, H.; Kalofonos, H.; Radulović, S.; Demey, W.; Ullén, A.; et al. Avelumab Maintenance Therapy for Advanced or Metastatic Urothelial Carcinoma. N. Engl. J. Med. 2020, 383, 1218-1230. [CrossRef] [PubMed]

104. Kirschner, A.N.; Wang, J.; Rajkumar-Calkins, A.; Neuzil, K.E.; Chang, S.S. Intravesical Anti-PD-1 Immune Checkpoint Inhibition Treats Urothelial Bladder Cancer in a Mouse Model. J. Urol. 2020. [CrossRef] [PubMed] 